\title{
Structural modification of eucalypt pulp lignin in a totally chlorine-free bleaching sequence including a laccase- mediator stage
}

\author{
Selected article from the $9^{\text {th }}$ EWLP, Vienna, Austria, August 27-30, 2006
}

\author{
David Ibarra1, María Isabel Chávez',2, \\ Jorge Rencoret ${ }^{3}$, José Carlos del Río ${ }^{3}$, Ana \\ Gutiérrez³, Javier Romero4, Susana Camarero', \\ María Jesús Martínez', Jesús Jiménez- \\ Barbero ${ }^{1}$ and Ángel T. Martínez ${ }^{1, *}$ \\ ${ }^{1}$ Centro de Investigaciones Biológicas, CSIC, Madrid, \\ Spain \\ 2 Instituto de Química, UNAM, Ciudad Universitaria, \\ Mexico \\ ${ }^{3}$ Instituto de Recursos Naturales y Agrobiología de \\ Sevilla, CSIC, Seville, Spain \\ ${ }^{4}$ CIT, ENCE, Pontevedra, Spain \\ ${ }^{*}$ Corresponding author. \\ Centro de Investigaciones Biológicas (CIB), CSIC, Ramiro de \\ Maeztu 9, E-28040 Madrid, Spain \\ E-mail: atmartinez@cib.csic.es
}

\begin{abstract}
Structural modification of eucalypt pulp lignin was investigated in a totally chlorine-free (TCF) bleaching sequence including a laccase-mediator stage. This stage was applied after two oxygen delignification stages, and was followed by an alkaline peroxide stage. After two oxygen delignification stages, two more stages with a laccase mediator and alkaline peroxide were applied. The residual lignins were enzymatically isolated from the different pulps and analyzed by spectroscopic techniques and analytical pyrolysis. The latter revealed high amounts of syringyl units $(>70 \%)$ in the lignins. ${ }^{13} \mathrm{C}-{ }^{-1} \mathrm{H}$ heteronuclear single quantum correlation (HSQC) NMR indicated high amounts of $\beta-0-4^{\prime}$ inter-unit linkages $(>75 \%$ sidechains). Changes in lignin composition and inter-unit linkages were demonstrated in the course of the bleaching sequence. Moreover, oxidative modification of the major syringyl units was shown by $\mathrm{C}_{2,6}-\mathrm{H}_{2,6}$ HSQC correlations and by the presence of oxidized pyrolysis markers in pyrograms. The existence of both $\mathrm{C}_{\alpha}$ keto and carboxyl groups in the residual lignin, together with normal $\left(\mathrm{C}_{\alpha}-\right.$ hydroxylated) units, was revealed by heteronuclear multiple bond correlation (HMBC) between aromatic $\mathrm{H}_{2,6}$ and side-chain carbons. These $\mathrm{C}_{\alpha}$-oxidized structures represent nearly $60 \%$ of total units in the lignin isolated from the enzymatically treated pulp. Analysis of residual lignin after the final peroxide stage compared with a simple alkaline treatment revealed that most of the oxidatively altered lignin was removed by the alkali used in the peroxide stage. Thus, the kappa number decreased and the final residual lignin was more structurally related to that found before the oxidative stages, although it contained less resinols and more carboxyl group-bearing units. However, the action of peroxide is necessary to attain the high brightness required (>90\% ISO).
\end{abstract}

Keywords: 2D NMR; enzymes; Eucalyptus globulus; FTIR; HMBC; HSQC; laccase-mediator system; paper pulp; Py-GC/MS; TCF bleaching.

\section{Introduction}

World consumption of eucalypt wood for paper pulp manufacturing has strongly increased during recent decades, including production of high-quality totally chlorine-free (TCF) bleached pulps. However, environmentally friendly bleaching of eucalypt paper pulps by oxygen and peroxide treatment does not always lead to the brightness levels and stability required.

Wood-rotting basidiomycetes are responsible for the natural degradation of lignin, a key step for carbon recycling in forest ecosystems (Martínez et al. 2005). Their oxidoreductases have high redox potential, and may be applied for delignifying and bleaching of paper-grade pulps (Bajpai 2004). Ligninolytic peroxidases were investigated as agents for environmentally sound bleaching of pulps, together with laccases (Paice et al. 1995). The interest in laccases as industrial biocatalysts increased after discovery of the laccase-mediator systems based on low-molecular-mass redox mediators (Bourbonnais and Paice 1990). More recently, $-\mathrm{N}(\mathrm{OH})$ - compounds have been reported as efficient laccase mediators in delignification of paper pulp (Poppius-Levlin et al. 1999b; Camarero et al. 2004; Chakar and Ragauskas 2004). Several issues remain to be solved before industrial implementation of the laccase-mediator system at the bleach plant level. Among them, the cost of mediators is still an obstacle, although some alternatives are being investigated (Camarero et al. 2005, 2007). New bleaching sequences have been suggested for high-quality pulps, in which laccase-mediator treatments are applied together with chemical reagents for bleaching of flax (García et al. 2003) and eucalypt TCF pulps (lbarra et al. 2006a).

For optimizing enzymatic delignification, knowledge about the chemical structure of lignin in terms of its $p$ hydroxyphenyl $(H)$, guaiacyl $(G)$, and syringyl $(S)$ phenylpropanoid units and inter-unit linkages is useful. Lignin isolation from hardwood pulps is one of the problems in these studies (Duarte et al. 2001). A procedure has been reported by lbarra et al. (2004) for enzymatic isolation of residual lignin from Eucalyptus globulus Labill pulp during TCF bleaching. Thus, lignin modification after bleaching could be studied (Ibarra et al. 2005). Compared with chemical isolation, this procedure yields unaltered lignin in moderate yield.

In the present study, residual lignin was enzymatically isolated from eucalypt kraft pulp, which was bleached in a laboratory TCF sequence including a laccase-mediator stage (lbarra et al. 2006a). Lignins were investigated by 
2D NMR, pyrolysis-gas chromatography/mass spectrometry (Py-GC/MS) and Fourier-transform infrared (FTIR) spectroscopy. Application of $2 \mathrm{D}$ NMR resulted in a powerful tool for lignin characterization, since signals overlapping in ${ }^{1} \mathrm{H}$ and ${ }^{13} \mathrm{C}$ NMR spectra are often resolved (Ralph et al. 1999). Two-dimensional NMR has been used to characterize residual lignins from different paper pulps (Balakshin et al. 2001a, 2003; Chen et al. 2003; Roost et al. 2003). This technique has been applied for analysis of eucalypt wood lignin (Evtuguin et al. 2001; Capanema et al. 2005), as well as residual lignin from eucalypt kraft pulps (Balakshin et al. 2001b; Capanema et al. 2001a,b; Ibarra et al. 2007). In spite of its potential, 2D NMR has only rarely been used to investigate lignin modification by laccase-mediators (Balakshin et al. 2001a; Ibarra et al. 2006b; Xu et al. 2006). On the other hand, Py-GC/ MS is helpful in studying the $S / G$ ratio and side-chain modification of lignins, and FTIR spectroscopy provides indication of the presence of functional groups (Faix 1992; del Río et al. 2001; Ibarra et al. 2005). Using a combination of these spectroscopic and degradative techniques, good insight can be obtained into the structural modifications of eucalypt pulp lignin occurring during enzymatic treatment and subsequent bleaching steps.

\section{Materials and methods}

\section{Enzyme-containing and control TCF bleaching sequences}

The enzyme-containing sequence was assayed in 4-I reactors containing $200 \mathrm{~g}$ of $E$. globulus kraft pulp ( $10 \%$ consistency) with a kappa number of 14.2 and a brightness of $41.2 \%$ ISO. The pulp was treated with laccase from Pycnoporus cinnabarinus (Jacq.) Fr. using a dose of $20 \mathrm{U} \mathrm{g}^{-1}$ dry weight (dw) in the presence of $1.5 \%$ (pulp dw) 1-hydroxybenzotriazole (HBT). The above enzymatic treatment (stage $\mathrm{L}$ ) was carried out under the following conditions: time, $2 \mathrm{~h} ; \mathrm{pH} 4$; temperature, $50^{\circ} \mathrm{C}$; and pressure, $6 \mathrm{~kg} \mathrm{~cm}^{-2} \mathrm{O}_{2}$. As described by lbarra et al. (2006a), the sequence (O-O-L-Q-PoP) also included two oxygen stages (O$O)$, a chelation stage $(Q)$, and an alkaline peroxide stage with a first step under pressurized oxygen (PoP). The control sequence (O-O-a-Q-PoP) included a stage under the same conditions as for stage L, but without laccase and mediator (stage a). A sample of O-O-L pulp was treated in parallel with $1.5 \% \mathrm{NaOH}$ (pulp $\mathrm{dw}$ ) for $1 \mathrm{~h}$ at $60^{\circ} \mathrm{C}$ (stage $\mathrm{E}$ ), and alkali lignin was precipitated at acidic $\mathrm{pH}$ after removal of solubilized polysaccharide with $50 \%$ ethanol. Pulp brightness, kappa number and viscosity were estimated by standard methods for up to four replicates (ISO 2003).

\section{Isolation and characterization of residual lignins}

Residual lignins were isolated after each stage of the above sequences (and from the alkali-treated O-O-L pulp) by cellulase hydrolysis, and purified with protease, dimethylacetamide (DMAC) and $\mathrm{NaOH}$ as described by lbarra et al. (2004). As already reported, the yield of enzymatic residual lignin was approximately $30 \%$ from unbleached eucalypt kraft pulp, and lower from bleached pulps, but the lignins obtained were not altered during isolation and exhibited a good degree of purity (lbarra et al. 2004, 2005).

Two-dimensional NMR spectra were recorded at $25^{\circ} \mathrm{C}$ in a Bruker AVANCE 500-MHz instrument using a z-gradient triple- resonance probe. Lignins $(40 \mathrm{mg}$ ) were dissolved in $0.75 \mathrm{ml}$ of DMSO- $d_{6}$, and spectra were recorded in HSQC (heteronuclear single quantum correlation) and HMBC (heteronuclear multiple bond correlation) experiments. The relaxation delay for the ${ }^{1} \mathrm{H}$ NMR spectrum was $7 \mathrm{~s}\left(90^{\circ}\right.$ pulse angle). The number of points collected was 32,000 . The ${ }^{1} \mathrm{H}$ NMR spectra were processed using an exponential weighting function of $0.2 \mathrm{~Hz}$ prior to Fourier transformation. The spectral widths for the HSQC were 5000 and $13,200 \mathrm{~Hz}$ for the ${ }^{1} \mathrm{H}$ and ${ }^{13} \mathrm{C}$ dimensions, respectively. For $\mathrm{HMBC}$, the ${ }^{13} \mathrm{C}$ dimension was increased to $30,000 \mathrm{~Hz}$. For both $\mathrm{HSQC}$ and HMBC, the number of complex points collected was 2048 for the ${ }^{1} \mathrm{H}$ dimension, with a recycle delay of $5 \mathrm{~s}$. The number of transients was 64 for the HSQC spectra, and 128 for $\mathrm{HMBC}$, and 256 time increments were always recorded in the ${ }^{13} \mathrm{C}$ dimension. The $\mathrm{J}$-coupling evolution delay was set to $3.2 \mathrm{~ms}$ in HSQC, while a long range $J$-coupling evolution time of $66 \mathrm{~ms}$ was applied for HMBC. In HSQC experiments, a squared cosine-bell apodization function was applied in both dimensions. Prior to Fourier transformation, the data matrixes were zero filled up to 1024 points in the ${ }^{13} \mathrm{C}$ dimension. Signals were assigned by combining experiments and comparing them with the literature (Ralph et al. 1999, 2004, 2006; Capanema et al. 2001a, 2004b, 2005; Balakshin et al. 2003; Liitiä et al. 2003).

Semi-quantitative analysis of the HSQC cross-signal intensities was performed (Heikkinen et al. 2003; Zhang and Gellerstedt 2007). Volume integration of the cross-signals was performed separately for the different regions of the HSQC spectra, which contain signals that correspond to chemically analogous carbon-proton pairs. For these signals, the ${ }^{1} J_{C H}$ coupling value is relatively similar and suitable for semi-quantitative estimation of the different $\mathrm{C}-\mathrm{H}$ correlations. In the aliphatic oxygenated region, inter-unit linkages were estimated from the $\mathrm{C}_{\alpha}-\mathrm{H}_{\alpha}$ correlations, except for structures $\mathbf{D}, \mathbf{E}$ and $\mathbf{J}$ described below, and the relative abundance of side chains involved in inter-unit linkages and terminal structures was calculated. The S/G ratio of lignin was estimated based on the aromatic $\mathrm{C}-\mathrm{H}$ correlations of $\mathrm{S}$ - and G-type units. The relative abundance of $\mathrm{C}_{\alpha}$-oxidized units, with respect to total aromatic units, was determined in the same way. The integrals were corrected for proton numbers.

FTIR spectra were obtained using a Bruker IF-28 spectrophotometer with $1 \mathrm{mg}$ of lignin in $300 \mathrm{mg}$ of $\mathrm{KBr}$, and the baseline was subtracted between valleys at ca. 1850 and $900 \mathrm{~cm}^{-1}$. Pyrolyses were performed in triplicate at $550^{\circ} \mathrm{C}$ (pyrolysis time 10 s) using a CDS Pyroprobe (with AS-2500 autosampler) coupled to Agilent GC (6890) and MS (5973 N) instruments. Separation was carried out on a DV-1701 column $(60 \mathrm{~m} \times 0.25 \mathrm{~mm}$, $0.25-\mu \mathrm{m}$ film) using a temperature program of $45^{\circ} \mathrm{C}$ for $4 \mathrm{~min}$, increased to $280^{\circ} \mathrm{C}$ at $4^{\circ} \mathrm{C} \mathrm{min}-1$ and $15 \mathrm{~min}$ at $280^{\circ} \mathrm{C}$. Lignin marker compounds were identified according to del Río et al. (2001).

\section{Results}

\section{Enzyme-containing and control sequences}

The main properties of eucalypt pulps from the bleaching sequences with (O-O-L-Q-PoP) and without enzyme (control, O-O-a-Q-PoP) are listed in Table 1, which also presents the characteristics of the laccase mediator pulp after alkaline treatment. Pulps with similar characteristics were found after $\mathrm{O}-\mathrm{O}$ (not shown) and $\mathrm{O}-\mathrm{O}$-a stages, confirming that the control stage did not affect pulp properties. The main chemical structures identified in the eucalypt pulp residual lignins are presented in Figure 1. 
Table 1 Main characteristics of the unbleached eucalypt kraft pulp, oxygen-delignified control pulp (O-O-a), oxygen-delignified pulp treated with laccase mediator (O-O-L), laccase mediator pulp after alkaline treatment (O-O-L-E), oxygen-delignified control pulp after chelation and peroxide stages (O-O-a-Q-PoP), and laccase mediator pulp after chelation and peroxide stages (O-O-L-Q-PoP).

\begin{tabular}{lcccccc}
\hline & \multicolumn{5}{c}{ Pulp } \\
\cline { 2 - 7 } & Kraft & O-O-a & O-O-L & O-O-L-E & O-O-a-Q-PoP & O-O-L-Q-PoP \\
\hline Kappa number & 14.2 & 10.3 & 8.6 & 5.4 & 6.7 & 5.2 \\
Hexenuronic acids (mEq kg-1) & 45.9 & 45.6 & 44.6 & - & 38.4 & 32.7 \\
Brightness (\% ISO) & 41.2 & 55.7 & 57.8 & 73.0 & 87.9 & 91.2 \\
Viscosity (ml g-1) & 1188 & 981 & 870 & 742 & 788 & 693 \\
\hline
\end{tabular}<smiles>CCOc1c(OC)cc(C(O)C(=CO)Oc2c(OC)cc(C(C)(C)C)cc2OC)cc1OC</smiles>

A<smiles>CCOc1c(OC)cc(C(O)C(CO)Oc2c(Cl)cc(C(=O)O)cc2OC)cc1OC</smiles>

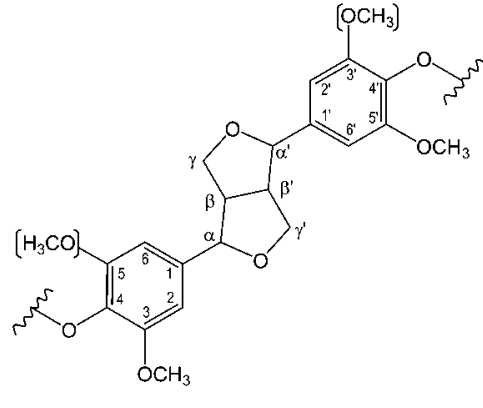

B<smiles>COc1cc(/C=C/CO)cc(OC)c1OC(F)(F)F</smiles><smiles>COc1cc(C2Oc3c(OC)cc(C(F)(F)F)cc3C2CO)cc(OC)c1OC(F)(F)F</smiles>

C<smiles>COc1cc(C(O)C(F)(F)F)ccc1OCC(C)(F)F</smiles><smiles>COc1cc(C(=O)P)ccc1O</smiles>

$\mathbf{G}^{\prime}$<smiles>[R]OC=C(Oc1c(O)cc([Z3])cc1OC)C(O[R])c1cc(OC)c(OC(F)(F)F)c(OC)c1</smiles>

I, J<smiles>COc1cc(C(O)C(=O)O)cc(OC)c1OC(F)(F)F</smiles>

$\mathbf{F}$

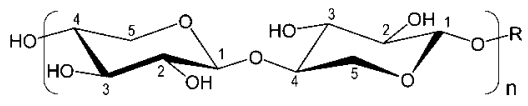

K
$\mathrm{CH}_{3}-\left(\mathrm{CH}_{2}\right)_{n}-\mathrm{COOR}$

$\mathbf{L}$<smiles>COc1cc(C(C)C)cc(OC)c1OCCO</smiles>

S<smiles>COc1cc(C(=O)C(C)C)cc(OC)c1O</smiles>

$\mathbf{S}^{\prime}$<smiles>COc1cc(C(=O)O)cc(OC)c1OC</smiles>

$\mathrm{S}^{\prime \prime}$

Figure 1 Main structures in eucalypt residual lignin: (A) $\beta-\mathrm{O}-4^{\prime}$; (B) resinol, formed by $\beta-\beta^{\prime}, \alpha-\mathrm{O}-\gamma^{\prime}$ and $\gamma-\mathrm{O}-\alpha^{\prime}$ linkages; (C) phenylcoumaran, formed by $\alpha-\mathrm{O}-4^{\prime}$ and $\beta-5^{\prime}$ linkages; (D) terminal $\beta-\mathrm{O}-4^{\prime}$ with $\mathrm{C}_{\alpha^{\prime}}$ carboxyl; (E) terminal $p$-hydroxycinnamyl alcohol; (F) $C_{\beta}$ carboxyl terminal unit; (G) guaiacyl unit; ( $\left.G^{\prime}\right)$ oxidized $G$ units with a $C_{\alpha}$ ketone (R, lignin) or carboxyl group $\left(R, O H\right.$; and $R^{\prime}$, lignin); (I, J) $\beta$-O-4' substructure $C_{\alpha}\left(R\right.$, polysaccharide; $\left.R^{\prime}, H\right)$ or $C_{\gamma}$ etherified to carbohydrate $\left(R, H\right.$; $R^{\prime}$, polysaccharide); $(K)$ xylan $\left(R\right.$, polysaccharide linked to lignin); (L) free $(R, H)$ or esterified fatty acids; $(\mathbf{S})$ syringyl unit; $\left(\mathbf{S}^{\prime}\right)$ oxidized syringyl unit with a $\mathrm{C}_{\alpha}$ ketone; and $\left(\mathbf{S}^{\prime \prime}\right)$ oxidized syringyl unit with a $\mathrm{C}_{\alpha}$ carboxyl. Only side-chain structures with relative abundance $>1 \%$ are presented. 

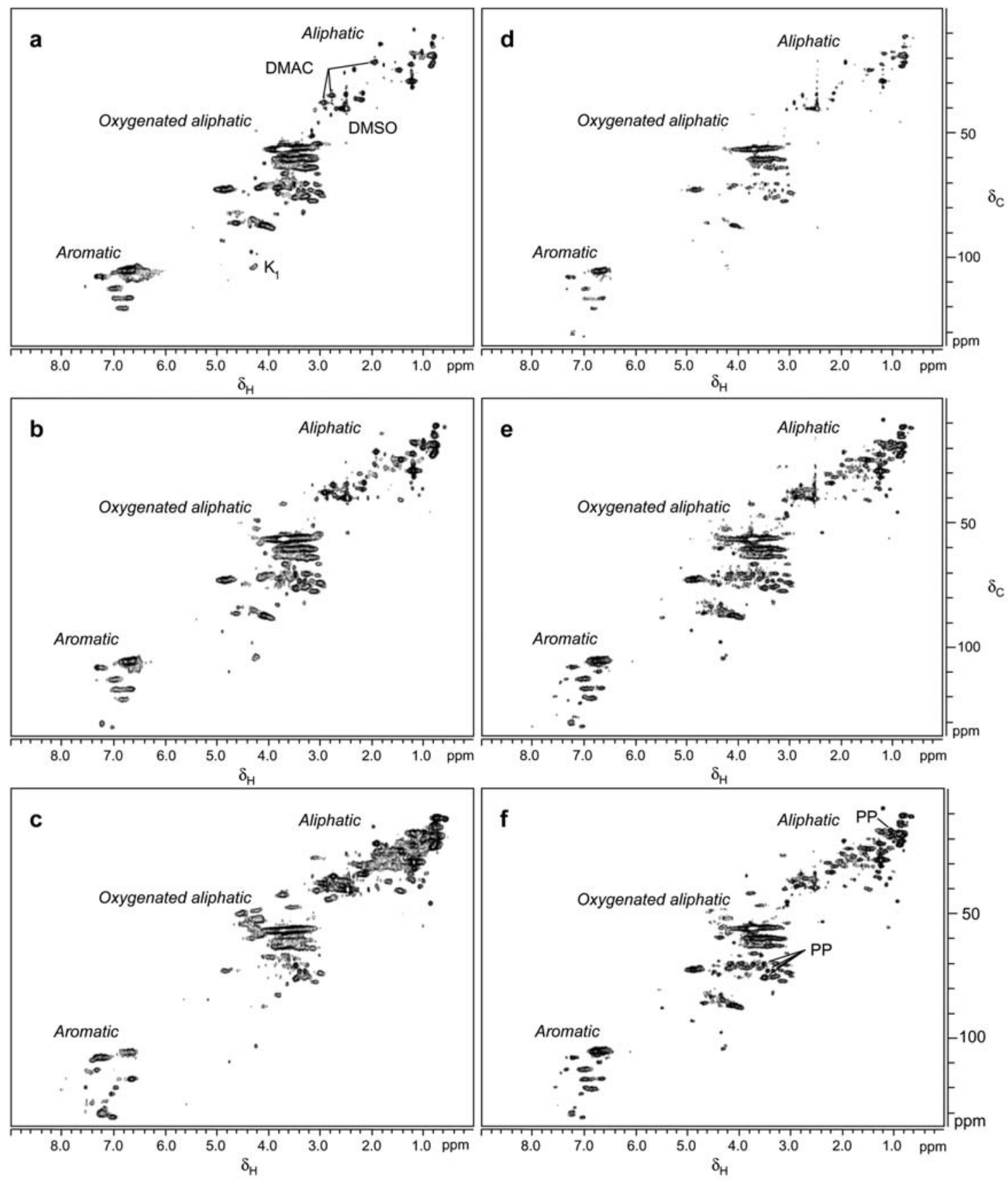

Figure 2 Complete HSQC spectra, $\delta_{C} / \delta_{H}$ 0-135/0-9 ppm, of lignins from: (a) unbleached kraft pulp; (b) O-O-a pulp; (c) O-O-L pulp; (d) O-O-L-E pulp; (e) O-O-a-Q-PoP pulp; and (f) O-O-L-Q-PoP pulp. Regions corresponding to aliphatic, oxygenated aliphatic (sidechain) and aromatic ${ }^{13} \mathrm{C}-{ }^{1} \mathrm{H}$ correlations are observed. Cross-signals for xylan and other polysaccharides, anomeric carbon $\left(\mathrm{K}_{1}\right)$, residual DMSO, and contaminating poly(ethyleneoxy-propyleneoxy) (PP) (Liitiä et al. 2003), and DMAC are visible in a and f, but they also appear in other samples and in Figure 3.

\section{NMR spectroscopy}

In HSQC spectra (Figure 2), regions can be distinguished for non-oxygenated and oxygenated aliphatic and for aromatic moieties (no signals with $\delta_{\mathrm{C}} 135-205$ ppm were found). The main ${ }^{13} \mathrm{C}-{ }^{-1} \mathrm{H}$ correlation signals assigned in the different HSQC spectra are listed in Table 2.

The first HSQC region, which contains cross-signals of extraneous materials (e.g., lipids) and unidentified lignin degradation products, was not analyzed in detail. The oxygenated aliphatic region (Figure 3 ) yields information about inter-unit linkages (A-C) and some terminal structures (D-F) and was suitable for semi-quantitative esti- mation of the relative abundances of the lignin side-chain structures mentioned above (Table 3). Some non-oxygenated side-chain correlations (namely $\mathbf{B}_{\beta}$ and $\mathbf{C}_{\beta}$ ) are included in the same expanded region because of their $\delta_{C} / \delta_{H}$ values. This region also contains cross-signals for xylans $(\mathbf{K})$ and other polysaccharides $\left(\delta_{\mathrm{C}} / \delta_{\mathrm{H}} \quad 67-75 /\right.$ 3.0-3.8 ppm) for which anomeric $\mathrm{C}_{1}-\mathrm{H}_{1}$ correlations are visible in Figure 2. Lignin-carbohydrate linkages were revealed by cross-signals for some $\beta-\mathrm{O}-4$ ' substructures that are $\mathrm{C}_{\alpha}$ or $\mathrm{C}_{\gamma}$-etherified with carbohydrates ( $\mathbf{I}$ and $\mathbf{J}$ ). The aromatic region (Figure 4) provides information on lignin constitutive units (such as $S$ and $G$ units), some of them bearing oxidized side chains $\left(S^{\prime}, S^{\prime \prime}\right.$ and $\left.G^{\prime}\right)$. 
Table 2 Assignment of main ${ }^{13} \mathrm{C}-{ }^{-1} \mathrm{H}$ correlation signals in the HSQC spectra shown in Figures 2-4.

\begin{tabular}{|c|c|}
\hline$\delta_{\mathrm{C}} / \delta_{\mathrm{H}}(\mathrm{ppm})$ & Assignment \\
\hline $53.7 / 3.42$ & $\mathrm{C}_{\beta}-\mathrm{H}_{\beta}$ in phenylcoumaran substructures (C) \\
\hline $54.1 / 3.04$ & $\mathrm{C}_{\beta}-\mathrm{H}_{\beta}$ in resinol substructures (B) \\
\hline $56.2 / 3.73$ & $\mathrm{C}-\mathrm{H}$ in methoxyls $(\mathrm{MeO})$ \\
\hline $60.1 / 3.40$ and 3.70 & $\mathrm{C}_{\gamma}-\mathrm{H}_{\gamma}$ in $\beta-\mathrm{O}-4^{\prime}$ substructures $(\mathbf{A})$ \\
\hline $61.9 / 4.09$ & $\mathrm{C}_{\gamma}-\mathrm{H}_{\gamma}$ in $p$-hydroxycinnamyl alcohol $(\mathrm{E})$ \\
\hline $63.4 / 3.20$ and 3.67 & $\mathrm{C}_{5}-\mathrm{H}_{5}$ in xylan $(\mathbf{K})$ \\
\hline $68.0 / 4.26$ & $\mathrm{C}_{\gamma}-\mathrm{H}_{\gamma}$ in $\beta-\mathrm{O}-4^{\prime}$ with $\mathrm{C}_{\gamma}$ etherified with carbohydrate $(\mathrm{J})$ \\
\hline $71.4 / 4.75$ & $\mathrm{C}_{\alpha}-\mathrm{H}_{\alpha}$ in $\beta-\mathrm{O}-4^{\prime}$ linked to a $\mathrm{G}$-type unit (A) \\
\hline $71.7 / 3.81$ and 4.17 & $\mathrm{C}_{\gamma}-\mathrm{H}_{\gamma}$ in resinol substructures $(\mathrm{B})$ \\
\hline $72.6 / 4.88$ & $\mathrm{C}_{\alpha}-\mathrm{H}_{\alpha}$ in $\beta-\mathrm{O}-4^{\prime}$ linked to an S-type unit (A) \\
\hline $73.5 / 3.01$ & $\mathrm{C}_{2}-\mathrm{H}_{2}$ in xylan $(\mathbf{K})$ \\
\hline $74.6 / 4.36$ & $\mathrm{C}_{\alpha}-\mathrm{H}_{\alpha}$ in $\mathrm{Ar}-\mathrm{CHOH}-\mathrm{COOH}$ units $(\mathbf{F})$ \\
\hline $75.3 / 3.32$ & $\mathrm{C}_{3}-\mathrm{H}_{3}$ in xylan $(\mathbf{K})$ \\
\hline $75.3 / 3.49$ & $\mathrm{C}_{4}-\mathrm{H}_{4}$ in xylan $(\mathbf{K})$ \\
\hline $83.0 / 4.54$ & $\mathrm{C}_{\beta}-\mathrm{H}_{\beta}$ in $\beta-\mathrm{O}-4^{\prime}$ with carboxyl in $\mathrm{C}_{\alpha^{\prime}}(\mathbf{D})$ \\
\hline $83.1 / 4.61$ & $\mathrm{C}_{\alpha}-\mathrm{H}_{\alpha}$ in $\beta-\mathrm{O}-4^{\prime} \mathrm{C}_{\alpha}$-etherified with carbohydrate (I) \\
\hline $84.1 / 4.29$ & $\mathrm{C}_{\beta}-\mathrm{H}_{\beta}$ in $\beta-\mathrm{O}-4^{\prime}$ linked to a G-type unit (A) \\
\hline $85.4 / 4.64$ & $\mathrm{C}_{\alpha}-\mathrm{H}_{\alpha}$ in resinol substructures $(\mathrm{B})$ \\
\hline $86.4-87.3 / 4.01-4.11^{\mathrm{a}}$ & $\mathrm{C}_{\beta}-\mathrm{H}_{\beta}$ in $\beta-\mathrm{O}-4^{\prime}$ linked to an S-type unit $(\mathbf{A})$ \\
\hline 87.5/5.46 & $\mathrm{C}_{\alpha}-\mathrm{H}_{\alpha}$ in phenylcoumaran substructures (C) \\
\hline 102.2/4.25 & $\mathrm{C}_{1}-\mathrm{H}_{1}$ in xylan $(\mathbf{K})$ \\
\hline 104.7/6.69 & $\mathrm{C}_{2,6}-\mathrm{H}_{2,6}$ in syringyl units $(\mathbf{S})$ \\
\hline 106.7/7.32 & $\mathrm{C}_{2,6}-\mathrm{H}_{2,6}$ in oxidized $\left(\mathrm{C}_{\alpha}=\mathrm{O}\right)$ syringyl units $\left(\mathbf{S}^{\prime}\right)$ \\
\hline 107.3/7.22 & $\mathrm{C}_{2,6}-\mathrm{H}_{2,6}$ in oxidized $\left(\mathrm{C}_{\alpha} \mathrm{OOH}\right)$ syringyl units $\left(\mathbf{S}^{\prime \prime}\right)$ \\
\hline 111.7/6.99 & $\mathrm{C}_{2}-\mathrm{H}_{2}$ in guaiacyl units $(\mathbf{G})$ \\
\hline $112.4 / 7.50$ & $\mathrm{C}_{2}-\mathrm{H}_{2}$ in oxidized guaiacyl units $\left(\mathbf{G}^{\prime}\right)$ \\
\hline $115.4 / 6.72$ and 6.94 & $\mathrm{C}_{5}-\mathrm{H}_{5}$ in guaiacyl units $(\mathbf{G})$ \\
\hline $119.6 / 6.81$ & $\mathrm{C}_{6}-\mathrm{H}_{6}$ in guaiacyl units $(\mathbf{G})$ \\
\hline 124.0/7.4 & $\mathrm{C}_{6}-\mathrm{H}_{6}$ in oxidized guaiacyl units $\left(\mathbf{G}^{\prime}\right)$ \\
\hline
\end{tabular}

a Including $\mathrm{C}_{\beta}-\mathrm{H}_{\beta}$ signals at $86.4 / 4.11$ and $87.3 / 4.01 \mathrm{ppm}$ corresponding to the erythro and threo forms, respectively, of side chains $\beta-\mathrm{O}-4^{\prime}$ linked to an $\mathrm{S}$ unit.

HMBC 2D NMR provides additional information on lignin quaternary carbons based on their correlations with protons at several-bond distances (Table 4). The former included methoxy-bearing $\mathrm{C}_{3}$ and $\mathrm{C}_{5}$ in lignin units, fattyacid (L) carboxyl carbons (Figure $5 \mathrm{a}, \mathrm{d}$ and $\mathrm{g}$ ) and especially keto and carboxyl $\mathrm{C}_{\alpha}$ in $\mathrm{S}^{\prime}$ and $\mathrm{S}^{\prime \prime}$ structures (Figure $5 b$, e and $h$ ).

\section{FTIR spectroscopy}

All spectra (Figure 6) present three bands between 1507 and $1419 \mathrm{~cm}^{-1}$ and the $1594 \mathrm{~cm}^{-1}$ band of aromatic ring vibrations. Other bands are due to ring breathing of $\mathrm{S}$ $\left(1328-1331 \mathrm{~cm}^{-1}\right)$ and $\mathrm{G}$ units $\left(1263-1266 \mathrm{~cm}^{-1}\right)$, in-plane bending of $S$ (1122-1126 $\left.\mathrm{cm}^{-1}\right)$ and $G$ units (1032-1039 $\mathrm{cm}^{-1}$ ), and out-of-plane bending of $\mathrm{G}$ $\left(913-916 \mathrm{~cm}^{-1}\right)$ and $S$ units $\left(833-836 \mathrm{~cm}^{-1}\right)$. Bands at 1655-1661 $\mathrm{cm}^{-1}$ and $1716-1717 \mathrm{~cm}^{-1}$ correspond to stretching of conjugated and non-conjugated carbonyls, respectively, although the former also includes amide bands and the latter carboxyl bands. The alkali lignin spectrum includes carbohydrate bands (around 1000 $\mathrm{cm}^{-1}$ ), together with lignin bands. Small bands at 745 and $770 \mathrm{~cm}^{-1}$ were assigned to benzotriazole formed from HBT during the enzymatic treatment of pulp, which incorporated into lignin.

\section{Analytical pyrolysis}

Lignin pyrograms (Figure 7) are dominated by peaks for guaiacol, syringol, and their 4-methyl, 4-ethyl, 4-vinyl, 4-propenyl, 4-propine and 4-allyl derivatives (Table 5). Aromatic aldehydes, ketones, and esters were also identified, as well as cinnamic-type aldehydes and alcohols. A small benzotriazole peak was observed (Figure 7b). Lignin S/G ratios and percentages of markers with oxidized and shortened side-chains were calculated. Some $\mathrm{H}$-type compounds, namely phenol and methylphenol, were detected. These only represented $0.5-0.6 \%$ of $\mathrm{Py}-\mathrm{GC} / \mathrm{MS}$ products, with the exception of unbleached kraft pulp lignin (0.3\%), alkali lignin (1\%) and O-O-L pulp lignin (up to $2.2 \%$ ). These compounds were accompanied by similar amounts of indole and 3-methylindole, assigned to protein tryptophan residues (Figure 7, asterisks).

\section{Discussion}

\section{Pulp lignin modification by laccase mediator (after oxygen delignification)}

Oxygen as a delignifying agent is widely introduced in paper pulp manufacture. There is a large body of literature on its effect on various residual lignins (Argyropoulos 2001), including eucalypt pulp lignin (Duarte et al. 2001; lbarra et al. 2007). Double oxygen delignification of $E$. globulus kraft pulp resulted in a decrease in kappa number (4 points) and increase in brightness (15 points). However, the structural characteristics of the residual lignin were not strongly affected, in agreement with other studies (Gellerstedt et al. 1999). The reason for this is that 

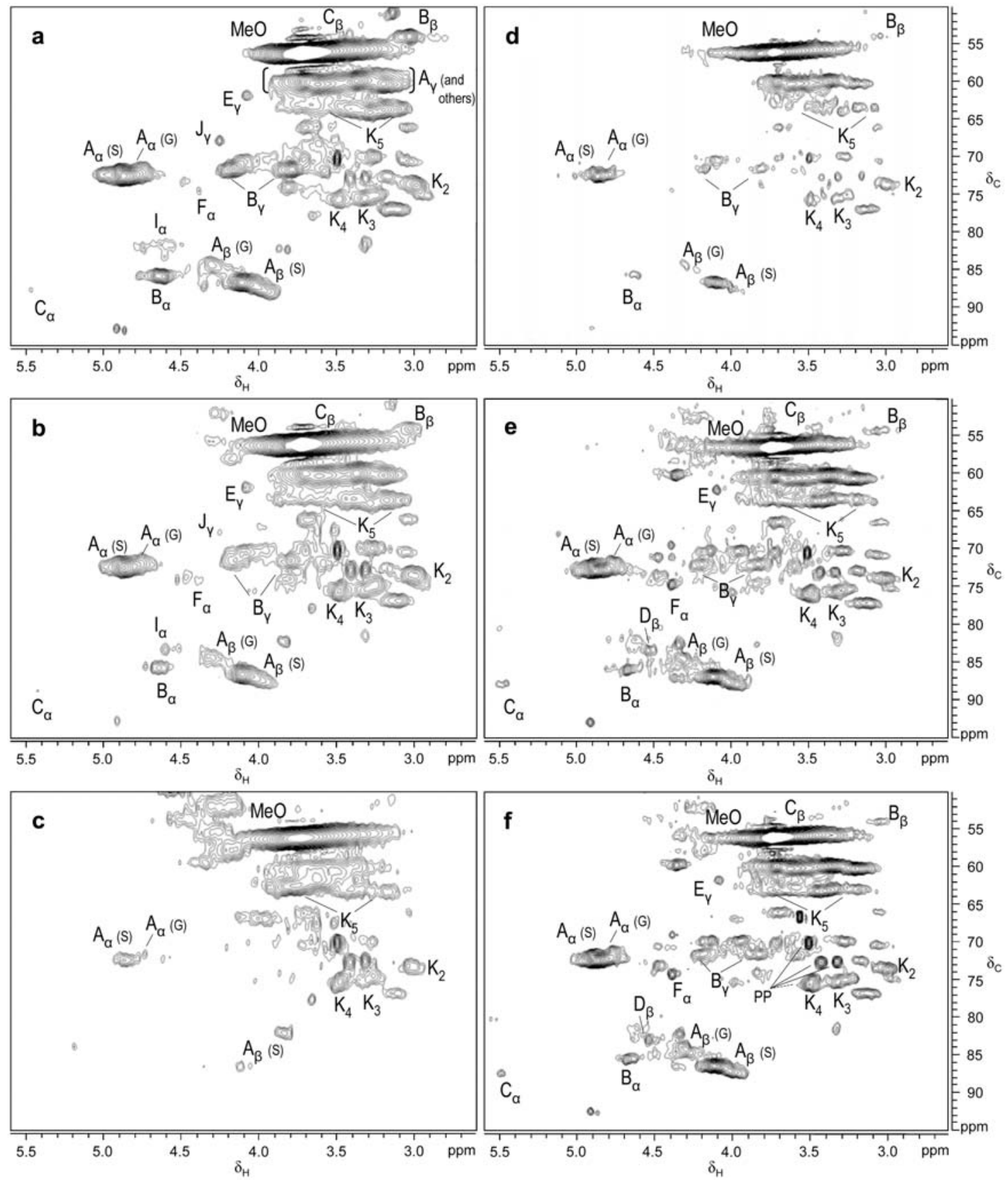

Figure 3 Expanded side-chain region, $\delta_{C} / \delta_{H} 50-95 / 2.6-5.6$ ppm, of the HSQC spectra of lignins from: (a) unbleached kraft pulp; (b) O-O-a pulp; (c) O-O-L pulp; (d) O-O-L-E pulp; (e) O-O-a-Q-PoP pulp; and (f) O-O-L-Q-PoP pulp. See Table 2 for signal assignment.

Table 3 Relative abundance of main inter-unit linkages and terminal structures as a percentage of total side chains from integration of ${ }^{13} \mathrm{C}-{ }^{-1} \mathrm{H}$ correlation signals in the HSQC spectra of lignins isolated from the enzyme-containing (O-O-L-Q-PoP) and control (O-O$\mathrm{a}-\mathrm{Q}-\mathrm{PoP})$ sequences, and the alkali lignin and residual lignin from the alkali-treated laccase-mediator pulp (O-O-L-E).

\begin{tabular}{|c|c|c|c|c|c|c|c|}
\hline & \multicolumn{7}{|c|}{ Linkage relative abundance in lignin (\%) } \\
\hline & Kraft pulp & O-O-a & O-O-L & Alkali & O-O-L-E & O-O-a-Q-PoP & O-O-L-Q-PoP \\
\hline$\beta-O-4^{\prime}(\mathbf{A})$ & 72 & 74 & 100 & 100 & 83 & 81 & 78 \\
\hline Resinol (B) & 17 & 15 & 0 & 0 & 13 & 6 & 9 \\
\hline Phenylcoumaran (C) & 1 & 1 & 0 & 0 & 0 & 3 & 3 \\
\hline$\beta-O-4^{\prime}$ with carboxyl in $C_{\alpha^{\prime}}(D)$ & 0 & 0 & 0 & 0 & 0 & 4 & 3 \\
\hline$p$-Hydroxycinnamyl alcohol (E) & 2 & 3 & 0 & 0 & 0 & 1 & 2 \\
\hline $\mathrm{Ar}-\mathrm{CHOH}-\mathrm{COOH}(\mathbf{F})$ & 2 & 2 & 0 & 0 & 3 & 4 & 4 \\
\hline $\begin{array}{l}\beta-\mathrm{O}-4^{\prime} \text { with } \mathrm{C}_{\alpha} \text { or } \mathrm{C}_{\gamma} \text { ether-linked } \\
\text { to carbohydrate }(\mathbf{I}, \mathbf{J})\end{array}$ & 6 & 4 & 0 & 0 & 0 & 0 & 0 \\
\hline
\end{tabular}



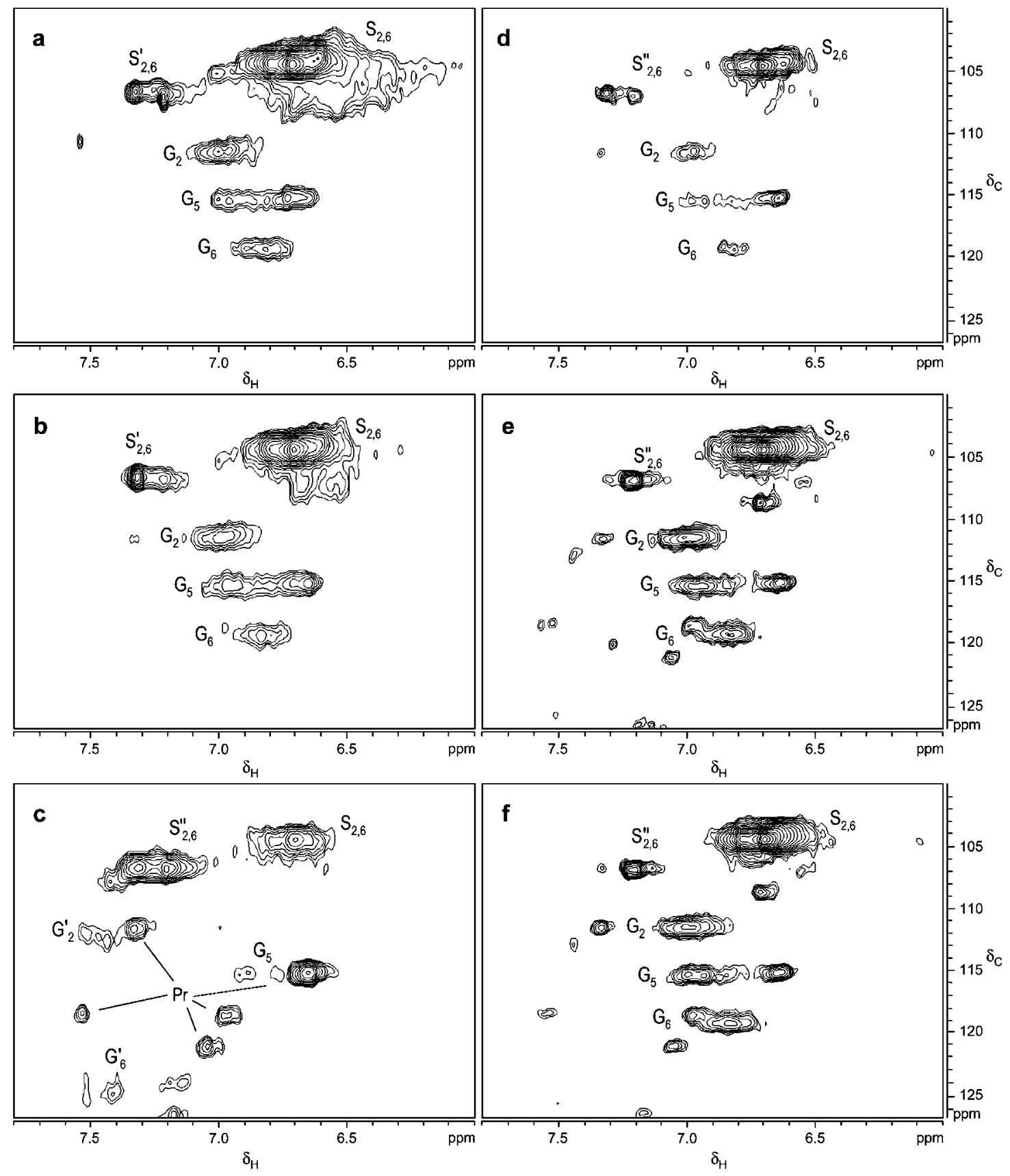

Figure 4 Expanded aromatic region, $\delta_{C} / \delta_{H} 100-127 / 6-7.8$ ppm, of the HSQC spectra of lignins from: (a) unbleached kraft pulp; (b) O-O-a pulp; (c) O-O-L pulp; (d) O-O-L-E pulp; (e) O-O-a-Q-PoP pulp; and (f) O-O-L-Q-PoP pulp. See Table 2 for signal assignment. Cross-signals for contaminating protein $(\mathrm{Pr})$ are also visible.

the altered lignin is removed from the pulp under the alkaline conditions. In contrast, the laccase mediator stage only slightly improved the kappa number and brightness of the oxygen-delignified pulp, but strongly modified the structural characteristics of the remaining lignin.

The eucalypt pulp residual lignin is rich in $S$ units, in agreement with in situ analyses based on Py-GC/MS of the whole pulp (del Río et al. 2001). In this context, it should be remembered that all degradation techniques preferentially affect the $S$ units of lignins. Thus, a correction factor of approximately $0.3-0.5$ has been suggested to calculate the true $S / G$ ratio (Sarkanen and Hergert 1971). The predominance of $S$ units in the eucalypt kraft pulp residual lignin was confirmed by the high intensity of $S$ cross-signals in the aromatic region of the HSQC spectra compared to those assigned to $G$ units. A decrease in $S / G$ ratio after the laccase mediator treatment was demonstrated by Py-GC/MS and FTIR spectroscopy ( $\mathrm{S} / \mathrm{G}$ estimation by HSQC NMR was hampered by the formation of oxidized structures), in agreement with enzymatic delignification of other angiosperm pulps (Poppius-Levlin et al. 1999a; Camarero et al. 2004).

A characteristic of the eucalypt pulp lignin isolated after the laccase mediator treatment is the presence of oxidized units. Oxidation of major $\mathrm{S}$ units was evidenced by the $\mathrm{C}_{2,6}-\mathrm{H}_{2,6}$ correlation signal with $\delta_{\mathrm{C}} / \delta_{\mathrm{H}}$ around 107/ 7.2-7.3 ppm, which appeared in the HSQC aromatic region together with the cross-signal at 105/6.7 ppm. $\mathrm{H}_{2,6}$ correlations in the HMBC spectra indicated that the latter 
Table 4 Assignment of ${ }^{13} \mathrm{C}-{ }^{-1} \mathrm{H}$ correlation signals involving lignin quaternary carbons in the HMBC spectra shown in Figure 5.

\begin{tabular}{|c|c|}
\hline$\delta_{\mathrm{C}} / \delta_{\mathrm{H}}(\mathrm{ppm})$ & Assignment \\
\hline $127.1 / 7.19$ & $\mathrm{C}_{1}-\mathrm{H}_{2,6}$ in oxidized $\left(\mathrm{C}_{\alpha} \mathrm{OOH}\right)$ syringyl units $\left(\mathbf{S}^{\prime \prime}\right)$ \\
\hline $127.1 / 7.32$ & $\mathrm{C}_{1}-\mathrm{H}_{2,6}$ in oxidized $\left(\mathrm{C}_{\alpha}=\mathrm{O}\right)$ syringyl units $\left(\mathbf{S}^{\prime}\right)$ \\
\hline $134.7 / 6.69$ & $\mathrm{C}_{1}-\mathrm{H}_{2,6}$ in syringyl units $(\mathbf{S})$ \\
\hline $138.4 / 6.69$ & $\mathrm{C}_{4}-\mathrm{H}_{2,6}$ in syringyl units $(\mathbf{S})$ \\
\hline $140.7 / 7.19$ & $\mathrm{C}_{4}-\mathrm{H}_{2,6}$ in oxidized $\left(\mathrm{C}_{\alpha} \mathrm{OOH}\right)$ syringyl units $\left(\mathbf{S}^{\prime \prime}\right)$ \\
\hline $141.5 / 7.32$ & $\mathrm{C}_{4}-\mathrm{H}_{2,6}$ in oxidized $\left(\mathrm{C}_{\alpha}=\mathrm{O}\right)$ syringyl units $\left(\mathbf{S}^{\prime}\right)$ \\
\hline $148.0 / 3.83$ & $\mathrm{C}_{3,5}-\mathrm{H}_{\mathrm{MeO}}$ in phenolic syringyl units $\left(\mathbf{S}^{\prime}\right)$ and $\mathrm{C}_{3}-\mathrm{H}_{\mathrm{MeO}}$ in $\mathbf{G}$ units \\
\hline 148.0/7.32 & $\mathrm{C}_{3,5}-\mathrm{H}_{2,6}$ in oxidized $\left(\mathrm{C}_{\alpha}=\mathrm{O}\right)$ syringyl units (phenolic) $\left(\mathbf{S}^{\prime}\right)$ \\
\hline $152.5 / 3.73$ & $\mathrm{C}_{3,5}-\mathrm{H}_{\mathrm{MeO}}$ in etherified syringyl units (S and $\left.\mathbf{S}^{\prime \prime}\right)$ \\
\hline $152.5 / 6.69$ & $\mathrm{C}_{3,5}-\mathrm{H}_{2,6}$ in etherified syringyl units $(\mathbf{S})$ \\
\hline $152.5 / 7.19$ & $\mathrm{C}_{3,5}-\mathrm{H}_{2,6}$ in oxidized $\left(\mathrm{C}_{\alpha} \mathrm{OOH}\right)$ syringyl units (etherified) $\left(\mathbf{S}^{\prime \prime}\right)$ \\
\hline $167.3 / 7.19$ & $\mathrm{C}_{\text {carboxyl }}-\mathrm{H}_{2,6}$ in oxidized $\left(\mathrm{C}_{\alpha} \mathrm{OOH}\right)$ syringyl units $\left(\mathbf{S}^{\prime \prime}\right)$ \\
\hline 170.0/1.78, 172.4/1.91 and 174.9/2.18 & $\mathrm{C}_{\text {carboxyl }}-\mathrm{H}_{\text {alkyl }}$ in fatty acids (L) \\
\hline $197.9 / 7.32$ & $\mathrm{C}_{\text {carbonyl }}-\mathrm{H}_{2,6}$ in oxidized $\left(\mathrm{C}_{\alpha}=\mathrm{O}\right)$ syringyl units $\left(\mathbf{S}^{\prime}\right)$ \\
\hline
\end{tabular}

signal corresponds to normal units bearing a hydroxyl in $\mathrm{C}_{\alpha}(\mathrm{S})$, whereas the former included two partially overlapping signals corresponding to oxidized units bearing a ketone $\left(\mathrm{S}^{\prime}\right.$ with $\left.\delta_{\mathrm{C}} 198 \mathrm{ppm}\right)$ or carboxyl group ( $\mathrm{S}^{\prime \prime}$ with $\left.\delta_{\mathrm{C}} 167 \mathrm{ppm}\right)$ in $\mathrm{C}_{\alpha}$. In addition to a higher degree of oxidation, the percentage of oxidized units was several-fold higher in residual lignin isolated from the O-O-L pulp (59\% of lignin units) than in the O-O residual lignin (10\% of units). Moreover, HMBC correlations, including $\mathrm{C}_{3,5^{-}}$ $\mathrm{H}_{2,6}$ cross-signals, indicated that the $\mathrm{S}$ (non oxidized) and $\mathrm{S}^{\prime \prime}$ (syringic acid) units were basically $\mathrm{C}_{4}$-etherified $\left(\delta_{\mathrm{C}}\right.$ $152 \mathrm{ppm}$ ), whereas the $S^{\prime}$ (syringone) units were predominantly phenolic $\left(\delta_{\mathrm{C}} 148 \mathrm{ppm}\right) .{ }^{1} \mathrm{H}$ NMR of acetylated lignin from eucalypt pulp (results not shown) indicated that the phenolic units left after oxygen delignification were not preferentially removed during laccase-HBT treatment.

The increase in conjugated carbonyls/carboxyls after laccase mediator treatment was confirmed by Py-GC/MS release of lignin markers with oxidized side chains, and FTIR bands at 1655-1661 and 1716-1717 $\mathrm{cm}^{-1}$. The former band is also typical of amide carbonyls from protein as confirmed by Py-GC/MS (indole and 3-methylindole markers) (Ibarra et al. 2004), and HSQC cross-signals of tyrosine (115/6.6 and 130/7.0 ppm; one of them overlapping with $\mathrm{C}_{5}-\mathrm{H}_{5}$ signal in $\mathrm{G}$ units), phenylalanine (129/7.2 ppm), and tryptophan residues (112/7.3, 119/ 7.0, 119/7.5, and 121/7.0 ppm). Based on the fact that contaminating protein was more abundant in the O-O-L lignin, we suggests that it originated from the laccase of the bleaching step, in addition to cellulase used in lignin isolation (Chen et al. 2003; Ibarra et al. 2004). As indicated by Py-GC/MS and FTIR, these samples also contain benzotriazole that was incorporated into the lignin during the laccase-HBT treatment. This compound interferes in protein estimation based on $\mathrm{N}$ content $(1-2 \% \mathrm{~N}$ can be found in most residual lignins, but up to $5 \% \mathrm{~N}$ after laccase mediator treatment). The enrichment in lignin $\mathrm{H}$ units during pulp delignification reported in other studies (Akim et al. 2001; Tamminen et al. 2003) is most probably due to contaminating protein, as tyrosine residues gives rise to the same Py-GC/MS products and HSQC correlations (Choi and Faix 1998).

Oxidized units have been detected in lignin from pine pulp based on G-unit $\mathrm{C}_{2}-\mathrm{H}_{2}$ and $\mathrm{C}_{6}-\mathrm{H}_{6}$ correlations (Balakshin et al. 2003). Small signals with $\delta_{C} / \delta_{H} 112 / 7.5$ and 124/7.4 ppm are indicative of traces of such units in residual lignin obtained from the O-O-L pulp, together with the oxidized $S$ units. The formation of conjugated carbonyls/carboxyls is a characteristic of oxygen delignification of pulp (Asgari and Argyropoulos 1998; Gierer 2000). These functional groups have also been detected after laccase mediator treatment using ${ }^{13} \mathrm{C}$ and ${ }^{31} \mathrm{P}$ NMR and FTIR spectroscopy (Sealey and Ragauskas 1998; Poppius-Levlin et al. 1999b; Chakar and Ragauskas 2004). The generation of $C_{\alpha}$-oxidized structures is congruent with the nature of the lignin biodegradation process, which has been described as an "enzymatic combustion" (Kirk and Farrell 1987). The action of laccase-HBT on some aromatic compounds is initiated by abstracting one electron and one proton from the $\mathrm{C}_{\alpha}$ atom (Cantarella et al. 2003). Aromatic ring oxidation (and cation radical formation) has also been reported during degradation of non-phenolic dimers by laccase-HBT. However, the $\mathrm{C}_{\alpha}$ attack followed by alkyl-aryl ether breakdown predominates and releases aromatic acids (Kawai et al. 2002). Our results confirm this, since the formation of syringic acid terminal units was the main lignin modification after eucalypt pulp treatment with laccase-HBT.

The major inter-unit linkages in E. globulus residual lignin belong to the $\beta-O-4^{\prime}$ and resinol types (Balakshin et al. 2001b). $\beta-O-4^{\prime}$ substructures (A) were highly predominant in all of the eucalypt residual lignins analyzed, with relative abundances of $>78 \%$ of side-chain structures. Approximately $6 \%$ of these structures were etherified with carbohydrates (see $\mathbf{I}$ and $\mathbf{J}$ in the residual lignin from kraft and oxygen-delignified pulps). Laccase mediator degradation did not uniformly affect the different eucalypt lignin substructures, as revealed by 2D NMR of the enzymatically isolated lignin. Resinols (B), accounting for $17 \%$ of side-chains in unbleached kraft pulp lignin and $15 \%$ in $0-0$ pulp lignin, were absent from lignin isolated after the laccase mediator treatment. Minor phenylcoumaran (C) substructures in kraft pulp lignin (1\%) were not modified by oxygen delignification. However, they were absent from the O-O-L lignin, and the same phenomenon was evident for the terminal sinapyl alcohol (E) and $\mathrm{C}_{\beta}$-oxidized structures $(\mathbf{F})$ that initially represented $2 \%$ of the side chains. The latter were tentatively assigned according to Balakshin et al. (2003). The $p$ - 


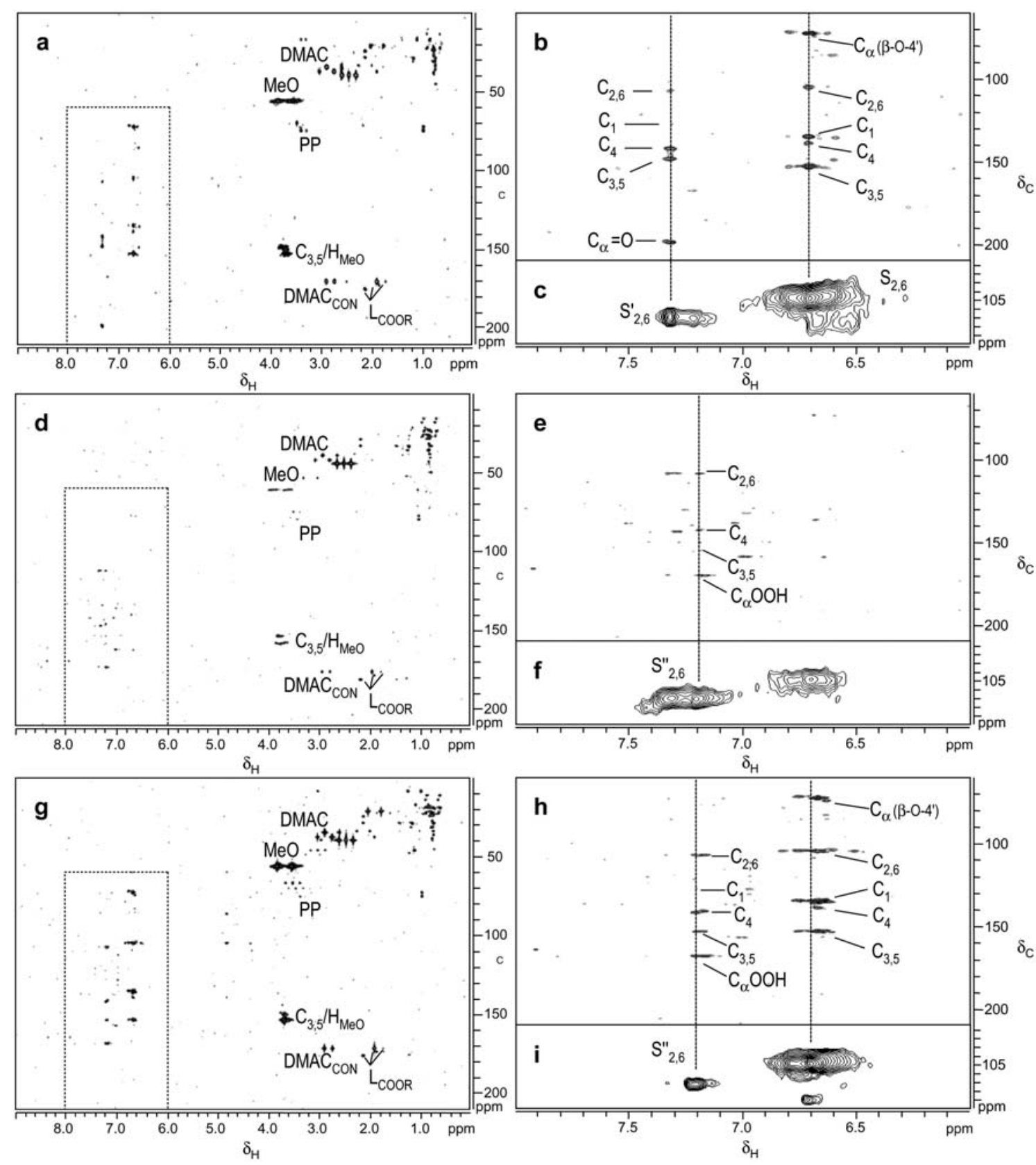

Figure 5 Total HMBC spectra, $\delta_{C} / \delta_{H}$ 0-210/0-9 ppm (a, d and g), and expanded, $\delta_{C} / \delta_{H} 60-210 / 6-8$ ppm (b, e and h) regions showing correlations between $\mathrm{H}_{2,6}$ and different carbons (dotted lines) in oxidized ( $\mathbf{S}^{\prime}$ and $\mathbf{S}^{\prime \prime}$ ) and non-oxidized (S) units (for which HSQC $\mathrm{C}_{2,6}-\mathrm{H}_{2,6}$ cross-signals are visible in c, $\mathrm{f}$ and i) of lignins from: (a-c) O-O-a pulp; (d-f) O-O-L pulp; and (g-i) O-O-L-Q-PoP pulp. Rectangles in $\mathrm{a}, \mathrm{d}$ and $\mathrm{g}$ indicate the region expanded in $\mathrm{b}$, e and $\mathrm{h}$. See Table 4 for signal assignment. Cross-signals for contaminating $\mathrm{PP}$ and a DMAC proton to amide carbon correlation ( $\left.\mathrm{DMAC}_{\mathrm{CoN}}\right)$ are visible in $\mathrm{a}, \mathrm{d}$ and $\mathrm{g}$.

hydroxycinnamyl alcohol structures most probably correspond to sinapyl alcohol because of the S-rich lignin in eucalypt pulp. The same applies to the resinol substructures that mainly correspond to syringaresinol, together with small amounts of pinoresinol and the S-G hybrid substructure. Spirodienones and dibenzodioxocins were absent from the eucalypt pulp lignins.

The 2D NMR spectra exhibit xylose and other carbohydrate cross-signals. Our interpretation is that the residual lignins are in fact lignin-carbohydrate complexes (Duarte et al. 2001). Cross-signals in residual lignins before the enzymatic stage revealed ether linkages between lignin $\mathrm{C}_{\alpha}$ or $\mathrm{C}_{\gamma}$ and polysaccharide primary hydroxyls (I and J) (Helm et al. 1997; Balakshin et al.
2003). These polysaccharides mainly contained xylose and glucose units (data not shown), in agreement with other studies (Capanema et al. 2004a). Therefore, the above ether linkages are most probably between lignin and glucopyranose units in eucalypt heteropolysaccharides (Shatalov et al. 1999; Evtuguin et al. 2003). A minor cross-signal with $\delta_{\mathrm{C}} / \delta_{\mathrm{H}} 102 / 4.9 \mathrm{ppm}$ was assigned to xylopyranose $\mathrm{C}_{1}$ forming a glycosidic-type linkage with a phenolic hydroxyl in lignin, as reported by Balakshin et al. (2001b), but its relative abundance was very low. The latter authors also suggested that $\mathrm{C}_{3}$ of xylan units in eucalypt residual lignins could be ether-linked to lignin. However, the preponderance of benzyl ether linkages with primary hydroxyls of carbohydrates is well estab- 


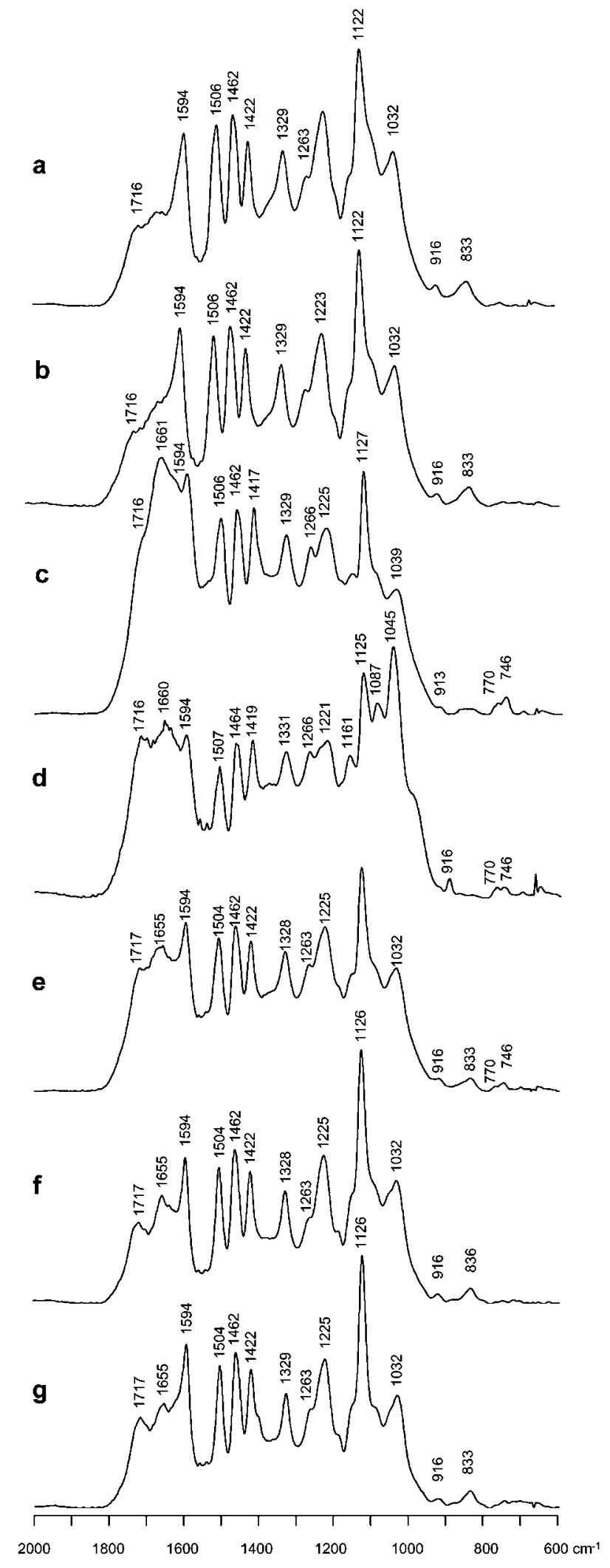

Figure 6 FTIR spectra (2000-600 $\left.\mathrm{cm}^{-1}\right)$ of: (a) unbleached kraft pulp lignin; (b) O-O-a pulp lignin; (c) O-O-L pulp lignin; (d) alkali lignin recovered after alkaline treatment of the O-O-L pulp; (e) O-O-L-E pulp lignin; (f) O-O-a-Q-PoP pulp lignin; and (g) O-OL-Q-PoP pulp lignin. See the text for band assignment.

lished (Koshijima and Watanabe 2003; Balakshin et al. 2007). Moreover, $C_{3}$ hydroxyl is often acetylated in eucalypt xylan (Evtuguin et al. 2003). Xylan and other carbo-

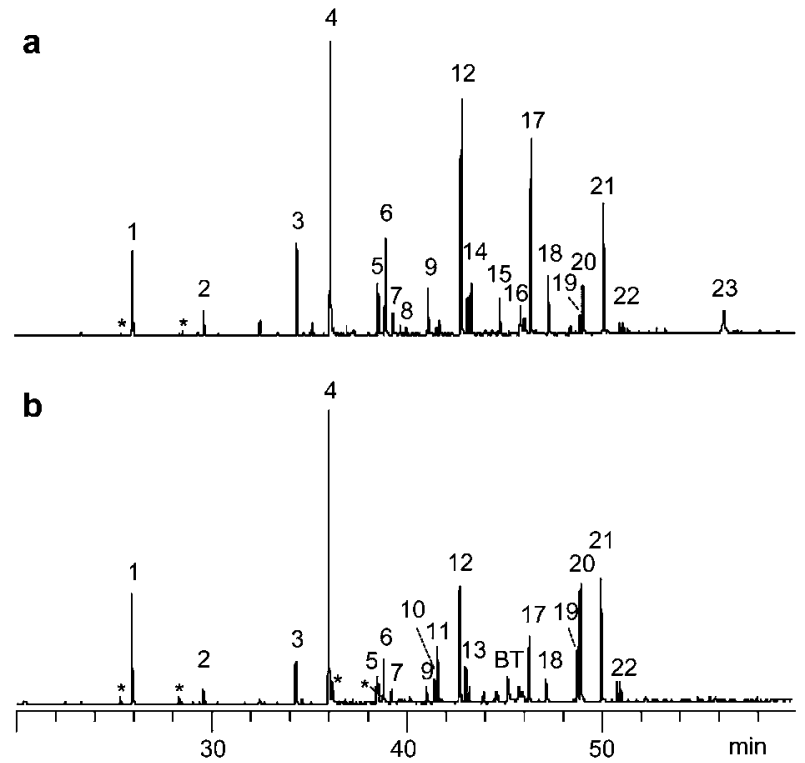

Figure 7 Py-GC/MS of lignins from (a) O-O-a pulp and (b) OO-L pulp. See Table 3 for peak identification. Minor peaks corresponding to phenol, 4-methylphenol, indole and 3-methyl indole (left to right) are indicated with asterisks, together with the benzotriazole (BT) peak in b.

hydrate cross-signals still showed high intensities after the laccase mediator treatment, while lignin side-chain cross-signals strongly decreased. Residual lignin isolated after the enzymatic treatment was also enriched in aliphatic non-oxygenated structures. These could include either lignin degradation products or complexes with pulp lipids (L), as indicated by HMBC NMR (alkyl-carboxyl correlations with $\left.\delta_{\mathrm{H}}<2.2 \mathrm{ppm}\right)$.

\section{Effect of alkaline peroxide after laccase mediator treatment of pulp}

Hydrogen peroxide is a common reagent in TCF sequences, often in combination with oxygen. Its action on pulp lignin has been investigated (Argyropoulos 2001), including eucalypt pulp in TCF bleaching (Ibarra et al. 2007). The peroxide stage decreased the kappa number by approximately 3.5 points for both the enzyme-containing and control sequences. Simultaneously, the ISO brightness increased by 32-33 points. The enhanced peroxide bleachability of pulps treated with laccase mediator is known (Sealey et al. 2000; Camarero et al. 2004; Ibarra et al. 2006a). The properties of the final product (brightness $>91 \%$ ISO and kappa number 2.4 corrected for the contribution of hexenuronic acids) indicate that the benefits of the laccase mediator stage were maintained (lbarra et al. 2006a). A moderate decrease in pulp viscosity occurred after laccase mediator treatment, but this was lower than that caused by other delignifying/ bleaching agents, such as $\mathrm{O}_{2}$ or $\mathrm{H}_{2} \mathrm{O}_{2}$, and can be prevented by a reductive stage (Camarero et al. 2004).

Alkaline peroxide strongly modified the characteristics of the O-O-L eucalypt pulp. A pulp bleached by O-O-L was additionally treated with alkali under PoP conditions to investigate the action mechanism of the alkaline peroxide stage. A strong decrease in kappa number and modification of residual lignin were observed after this 
Table $5 \mathrm{Py}-\mathrm{GC} / \mathrm{MS}$ of the lignins isolated from eucalypt pulps in the course of the bleaching sequence including a laccase mediator stage (O-O-L-Q-PoP) and the control sequence (O-O-a-Q-PoP), as well as the alkali lignin and residual lignin (O-O-L-E) from alkalitreated pulp.

\begin{tabular}{|c|c|c|c|c|c|c|c|}
\hline & \multicolumn{7}{|c|}{ Mean molar abundance in lignin ${ }^{a}$} \\
\hline & Kraft pulp & $\mathrm{O}-\mathrm{O}-\mathrm{a}$ & O-O-L & Alkali & O-O-L-E & O-O-a-Q-PoP & O-O-L-Q-PoP \\
\hline 1. Guaiacol & 6.1 & 6.5 & 11.9 & 13.5 & 5.9 & 3.8 & 3.9 \\
\hline 2. 4-Methylguaiacol & 1.7 & 1.8 & 1.5 & 1.7 & 1.4 & 1.5 & 3.1 \\
\hline 3. 4-Vinylguaiacol & 6.2 & 6.3 & 3.9 & 2.6 & 6.4 & 5.9 & 5.8 \\
\hline 4. Syringol & 18.4 & 19.3 & 24.8 & 28.2 & 18.7 & 13.8 & 15.1 \\
\hline 5. $t$-Isoeugenol & 3.3 & 3.2 & 1.3 & 2.2 & 2.5 & 2.5 & 2.1 \\
\hline 6. 4-Methylsyringol & 4.8 & 4.9 & 3.2 & 3.3 & 4.7 & 6.0 & 13.3 \\
\hline 7. Vanillin & 1.0 & 1.4 & 1.3 & 1.2 & 1.1 & 0.8 & 0.8 \\
\hline 8. Propine-guaiacol & 1.1 & 0.5 & 0.3 & 0.0 & 1.5 & 1.0 & 0.2 \\
\hline 9. 4-Ethylsyringol & 1.4 & 1.9 & 1.1 & 1.2 & 1.6 & 1.3 & 3.2 \\
\hline 10. Methyl vanillate & 0.3 & 0.3 & 1.7 & 1.5 & 0.0 & 0.5 & 0.6 \\
\hline 11. Acetoguaiacone & 0.8 & 0.9 & 4.4 & 3.8 & 1.1 & 0.5 & 0.4 \\
\hline 12. 4-Vinylsyringol & 14.5 & 14.2 & 7.3 & 4.9 & 16.5 & 18.4 & 17.0 \\
\hline 13. Guaiacyl-acetone & 1.5 & 1.8 & 2.4 & 3.7 & 1.3 & 1.4 & 1.7 \\
\hline 14. 4-Allylsyringol & 2.2 & 2.4 & 0.9 & 0.6 & 2.0 & 2.6 & 2.7 \\
\hline 15. c-Propenylsyringol & 1.3 & 1.6 & 0.7 & 0.0 & 1.3 & 1.5 & 1.4 \\
\hline 16. Propine-syringol & 7.7 & 3.2 & 3.7 & 0.0 & 8.3 & 8.5 & 3.4 \\
\hline 17. $t$-Propenylsyringol & 8.8 & 9.7 & 4.0 & 2.3 & 9.2 & 10.2 & 9.2 \\
\hline 18. Syringaldehyde & 3.0 & 3.4 & 2.2 & 2.3 & 2.6 & 2.8 & 2.4 \\
\hline 19. Methyl syringate & 0.5 & 0.8 & 3.5 & 2.8 & 0.8 & 1.3 & 1.4 \\
\hline 20. Acetosyringone & 2.6 & 2.6 & 7.8 & 6.5 & 2.7 & 2.1 & 1.3 \\
\hline 21. Syringylacetone & 5.1 & 6.6 & 7.6 & 13.3 & 6.7 & 6.3 & 7.4 \\
\hline 22. Propiosyringone & 0.5 & 0.5 & 1.2 & 0.6 & 0.4 & 0.3 & 0.6 \\
\hline 23. t-Synapaldehyde & 3.4 & 2.7 & 0.0 & 0.0 & 2.0 & 4.0 & 1.2 \\
\hline S/G ratio & 3.0 & 3.0 & 2.3 & 2.2 & 3.5 & 3.9 & 4.0 \\
\hline $\mathrm{C}_{6}-\mathrm{C}=\mathrm{O}(\%)^{\mathrm{b}}$ & 16.4 & 19.4 & 34.2 & 38.8 & 17.1 & 16.8 & 16.9 \\
\hline $\mathrm{C}_{6}-\mathrm{C}_{0-1}(\%)^{\mathrm{c}}$ & 36.1 & 38.7 & 50.2 & 54.5 & 35.3 & 30.6 & 40.5 \\
\hline
\end{tabular}

a Mean molar abundances of Py-GC/MS markers attaining $1 \%$ in at least one sample.

bPercentage of markers bearing a carboxyl/carbonyl group.

c Percentage of markers bearing side chains of 0-1 $\mathrm{C}$ atoms.

alkaline treatment. The brightness was only slightly improved. Two-dimensional NMR showed that the soluble alkali lignin was structurally related to the enzymatic lignin isolated from the O-O-L pulp. It was characterized by the presence of $\beta-O-4^{\prime}$ substructures, and over $25 \%$ of $\mathrm{C}_{\alpha}$-oxidized units with respect to the total aromatic units. The latter finding is in agreement with the higher percentage of oxidized side-chain markers detected by $\mathrm{Py}-\mathrm{GC} / \mathrm{MS}$. These results, together with the analysis of the O-O-L-E residual lignin that had only $10 \%$ oxidized units, as shown by HSQC NMR, reveal that the PoP alkaline conditions are responsible for the decrease in kappa number, which is due to alkali removal of the oxidized lignin formed during the laccase mediator stage. Moreover, the presence of a strongly oxidized lignin fraction, which will be preferentially recovered during enzymatic isolation of lignin, explains the structural characteristics of the O-O-L residual lignin described above. A more complete study on the effect of laccase-HBT on pulp lignin, including the alkali-extractable fraction and that remaining in pulp, is not possible owing to the moderate yield of residual lignin. The need for alkaline treatment for pulp delignification after oxidative enzymatic treatment is known from other biobleaching studies (Bourbonnais and Paice 1996). Release of altered lignin, including $\mathrm{C}_{\alpha}$-oxidized units, has been described by Balakshin et al. (2001a) during alkaline extraction of pine pulp treated with laccase-HBT. The alkali lignin extracted from eucalypt pulp treated with laccase mediator was also rich in carbohydrates, in agreement with results reported by the latter authors.

The action of hydrogen peroxide was required for a significant improvement in eucalypt pulp brightness. This was correlated with a nearly $50 \%$ decrease in resinol substructures (only $6-9 \%$ of the side chains left) and detection of phenylcoumaran (3\%) and sinapyl (1-2\%) structures. A very small cross-signal was found after peroxide treatment, with $\delta_{\mathrm{C}} / \delta_{\mathrm{H}} 80.2 / 5.49 \mathrm{ppm}$, corresponding to $\mathrm{C}_{\alpha}-\mathrm{H}_{\alpha}$ in $\alpha-\mathrm{O}-4^{\prime} / \beta-\mathrm{O}-4^{\prime \prime}$ substructures (Ämmälahti et al. 1998). The peroxide treatment decreased the total amount of conjugated carbonyls/carboxyls. These chromophoric groups amounted to only $5-7 \%$ in the final residual lignin. Accordingly, conjugated ketones $\left(\mathrm{S}^{\prime}\right)$ were absent, whereas some terminal structures with conjugated $\left(\mathrm{S}^{\prime \prime}\right)$ and non-conjugated (F) carboxyls were still visible in the 2D NMR spectra. An increase in carboxyls has been described after peroxide bleaching of other pulps (Gellerstedt et al. 1999). The high intensity of the FTIR band around $1720 \mathrm{~cm}^{-1}$ is a clear indication of this (Hortling et al. 1997). We also observed this phenomenon for the O-O-Q-PoP eucalypt lignin compared to the spectrum of the $\mathrm{O}-\mathrm{O}$ lignin. By contrast, residual lignins after O-O-L-Q-PoP and O-O-a-Q-PoP sequences failed to reveal any structural changes that could be correlated to the improvement in pulp properties after laccase mediator treatment (in particular the brightness increase). This indicates that no chromophoric groups were specifically destroyed by the laccase mediator treatment. We sug- 
gest that the improvement in final brightness is mainly due to a lower lignin content caused by enzymatic delignification.

\section{Acknowledgements}

This study was funded by Spanish projects $\mathrm{BIO} 2005-03569$, AGL2005-01748 and CTQ2005-08925-C02-02, EU contracts QLK3-99-590 and NMP2-CT-2006-26456, CSIC project 2006-4OI-39, and two ENCE-CSIC contracts. Angeles Canales (CIB, CSIC, Madrid) is acknowledged for help in the NMR studies, and Alicia Prieto (CIB, CSIC, Madrid) for polysaccharide analysis. Beldem (Andenne, Belgium) is acknowledged for the laccase sample. D.I. and J.R. are grateful for I3P Fellowships from the Spanish CSIC, and S.C. acknowledges an R\&C contract from the Spanish MEC.

\section{References}

Akim, L.G., Colodette, J.L., Argyropoulos, D.S. (2001) Factors limiting oxygen delignification of kraft pulp. Can. J. Chem. 79:201-210.

Ämmälahti, E., Brunow, G., Bardet, M., Robert, D., Kilpeläinen, I. (1998) Identification of side-chain structures in a poplar lignin using three-dimensional HMQC-HOHAHA NMR spectroscopy. J. Agric. Food Chem. 46:5113-5117.

Argyropoulos, D.S. Oxidative Delignification Chemistry: Fundamentals and Catalysis. ACS, Washington, DC, 2001.

Asgari, F., Argyropoulos, D.S. (1998) Fundamentals of oxygen delignification. Part II. Functional group formation elimination in residual kraft lignin. Can. J. Chem. 76:1606-1615.

Bajpai, P. (2004) Biological bleaching of chemical pulps. Crit Rev. Biotechnol. 24:1-58.

Balakshin, M., Capanema, E., Chen, C.-L., Gratzl, J., Kirkman, A., Gracz, H. (2001a) Biobleaching of pulp with dioxygen in the laccase-mediator system-reaction mechanisms for degradation of residual lignin. J. Mol. Cat. B: Enzym. 13:1-16.

Balakshin, M.Y., Evtuguin, D.V., Neto, C.P., Silva, A.M.S., Domingues, P., Amado, F.M.L. (2001b) Studies on lignin and lignin-carbohydrate complex by application of advanced spectroscopic techniques. In: Proceedings of the 11th ISWP Conference, Nice, 11-14 June 200. pp. 103-106.

Balakshin, M.Y., Capanema, E.A., Chen, C.-L., Gracz, H.S. (2003) Elucidation of the structures of residual and dissolved pine kraft lignins using an HMQC NMR technique. J. Agric. Food Chem. 51:6116-6127.

Balakshin, M.Y., Capanema, E.A., Chang, H. (2007) MWL fraction with a high concentration of lignin-carbohydrate linkages: Isolation and 2D NMR spectroscopic analysis. Holzforschung 61:1-7.

Bourbonnais, R., Paice, M.G. (1990) Oxidation of non-phenolic substrates. An expanded role for laccase in lignin biodegradation. FEBS Lett. 267:99-102.

Bourbonnais, R., Paice, M.G. (1996) Enzymatic delignification of kraft pulp using laccase and a mediator. Tappi J. 79:199-204.

Camarero, S., García, O., Vidal, T., Colom, J., del Río, J.C., Gutiérrez, A., Gras, J.M., Monje, R., Martínez, M.J., Martínez, A.T. (2004) Efficient bleaching of non-wood high-quality paper pulp using laccase-mediator system. Enzyme Microb. Technol. 35:113-120.

Camarero, S., Ibarra, D., Martínez, A.T., Romero, J., Gutiérrez, A., del Río, J.C. (2007) Paper pulp delignification using laccase and natural mediators. Enzyme Microb. Technol. 40: 1264-1271.

Camarero, S., Ibarra, D., Martínez, M.J., Martínez, A.T. (2005) Lignin-derived compounds as efficient laccase mediators for decolorization of different types of recalcitrant dyes. Appl. Environ. Microbiol. 71:1775-1784.
Cantarella, G., Galli, C., Gentili P. (2003) Free radical versus electron-transfer routes of oxidation of hydrocarbons by laccasemediator systems. Catalytic and stoichiometric procedures. J. Mol. Cat. B: Enzym. 22:135-144.

Capanema, E.A., Balakshin, M.Y., Chen, C.L. (2004a) An improved procedure for isolation of residual lignins from hardwood kraft pulps. Holzforschung 58:464-472.

Capanema, E.A., Balakshin, M.Y., Chen, C.-L., Gratzl, J.S. Gracz, H. (2001a) Structural analysis of residual and technical lignins by ${ }^{1} \mathrm{H}-{ }^{13} \mathrm{C}$ correlation 2D NMR spectroscopy. Holzforschung 55:302-308.

Capanema, E.A., Balakshin, M.Y., Chen, C.-L., Gratzl, J.S., Gracz, H.S. (2001b) Studies on kraft pulp lignins using HMQC NMR techniques. In: Proceedings of the 7th Brazilian Symposium on Chemistry of Lignin and Other Wood Components, Belo Horizonte, MG, Brazil. pp. 61-68.

Capanema, E.A., Balakshin, M.Y., Kadla, J.F. (2004b) A comprehensive approach for quantitative lignin characterization by NMR spectroscopy. J. Agric. Food Chem. 52:1850-1860.

Capanema, E.A., Balakshin, M.Y., Kadla, J.F. (2005) Quantitative characterization of a hardwood milled wood lignin by nuclear magnetic resonance spectroscopy. J. Agric. Food Chem. 53:9639-9649.

Chakar, F.S., Ragauskas, A.J. (2004) Biobleaching chemistry of laccase-mediator systems on high-lignin-content kraft pulps. Can. J. Chem. 82:344-352.

Chen, C.-L., Capanema, E.A., Gracz, H.S. (2003) Comparative studies on the delignification of pine kraft-anthraquinone pulp with hydrogen peroxide by binucleus $\mathrm{Mn}(\mathrm{IV})$ complex catalysis. J. Agric. Food Chem. 51:6223-6232.

Choi, J.-W., Faix, O. (1998) Characterization of residual lignins isolated from different chemical pulps of spruce and beach through enzymatic hydrolysis by spectroscopy and chemical degradations. In: Proceedings of the 5th European Workshop on Lignocellulosics and Pulp, August 30-September 2, Aveiro, Portugal. pp. 527-530.

del Río, J.C., Gutiérrez, A., Romero, J., Martínez, M.J., Martínez, A.T. (2001) Identification of residual lignin markers in eucalypt kraft pulps by Py-GC/MS. J. Anal. Appl. Pyrolysis 58/59: 425-433.

Duarte, A.P., Robert, D., Lachenal, D. (2001) Eucalyptus globulus kraft pulp residual lignin. Part 2. Modification of residual lignin structure in oxygen bleaching. Holzforschung 55:645-651.

Evtuguin, D.V., Neto, C.P., Silva, A.M.S., Domingues, P.M., Amado, F.M.L., Robert, D., Faix, O. (2001) Comprehensive study on the chemical structure of dioxane lignin from plantation Eucalyptus globulus wood. J. Agric. Food Chem. 49: 4252-4261.

Evtuguin, D.V., Tomas, J.L., Silva, A.M., Neto, C.P. (2003) Characterization of an acetylated heteroxylan from Eucalyptus globulus Labill. Carbohyd. Res. 338:597-604.

Faix, O. (1992) Fourier transform infrared spectroscopy. In: Methods in Lignin Chemistry. Eds. Lin, S.Y., Dence, C.W. Springer-Verlag, Berlin. pp. 83-109.

García, O., Camarero, S., Colom, J., Martínez, A.T., Martínez, M.J., Monje, R., Vidal, T. (2003) Optimization of a laccasemediator stage for TCF bleaching of flax pulp. Holzforschung 57:513-519.

Gellerstedt, G., Heuts, L., Robert, D. (1999) Structural changes in lignin during a totally chlorine free bleaching sequence. Part II: An NMR study. J. Pulp Pap. Sci. 25:111-117.

Gierer, J. (2000) The interplay between oxygen-derived radical species in the delignification during oxygen and hydrogen peroxide bleaching. In: Lignin: Historical, Biological, and Materials Perspectives. Eds. Glasser, W.G., Northey, R.A., Schultz., T.P. ACS, Washington, DC.

Heikkinen, S., Toikka, M.M., Karhunen, P.T., Kilpeläinen, I.A. (2003) Quantitative 2D HSQC (Q-HSQC) via suppression of $J$-dependence of polarization transfer in NMR spectroscopy: Application to wood lignin. J. Am. Chem. Soc. 125: 4362-4367. 
Helm, R.F., Toikka, M., Li, K.C., Brunow, G. (1997) Lignin model glycosides: Preparation and optical resolution. J. Chem. Soc. Perkin Trans. 1:533-537.

Hortling, B., Tamminen, T., Kentta, E. (1997) Determination of carboxyl and non-conjugated carbonyl groups in dissolved and residual lignins by IR spectroscopy. Holzforschung 51:405-410.

Ibarra, D., del Río, J.C., Gutiérrez, A., Rodríguez, I.M., Romero, J., Martínez, M.J., Martínez, A.T. (2004) Isolation of high-purity residual lignins from eucalypt paper pulps by cellulase and proteinase treatments followed by solvent extraction. Enzyme Microb. Technol. 35:173-181.

Ibarra, D., del Río, J.C., Gutiérrez, A., Rodríguez, I.M., Romero, J., Martínez, M.J., Martínez, A.T. (2005) Chemical characterization of residual lignins from eucalypt paper pulps. J. Anal. Appl. Pyrolysis 74:116-122.

Ibarra, D., Camarero, S., Romero, J., Martínez, M.J., Martínez, A.T. (2006a) Integrating laccase-mediator treatment into an industrial-type sequence for totally chlorine free bleaching eucalypt kraft pulp. J. Chem. Technol. Biotechnol. 81: 1159-1165.

Ibarra, D., Chávez, M.I., Rencoret, J., del Río, J.C., Gutiérrez, A., Romero, J., Camarero, S., Martínez, M.J., Jiménez-Barbero, J., Martínez, A.T. (2006b) Chemical characterization of eucalypt pulp lignin during totally chlorine free bleaching including a laccase-mediator stage: 2D-NMR, FTIR and Py-GC/MS of enzymatically-isolated residual lignins. In: Proceedings of the 9th EWLP, Vienna, 27-30 August 2006.

Ibarra, D., Chávez, M.I., Rencoret, J., del Río, J.C., Gutiérrez, A., Romero, J., Camarero, S., Martinez, M.J., Jiménez-Barbero, J., Martínez, A.T. (2007) Lignin modification during Eucalyptus globulus kraft pulping followed by totally chlorine free bleaching: A two-dimensional nuclear magnetic resonance, Fourier transform infrared, and pyrolysis-gas chromatography/mass spectrometry study. J. Agric. Food Chem. 55: 3477-3490.

International Organisation for Standardization, Documentation and Information. ISO Standards Collection on CD-ROM. Paper, Board and Pulps. ISO, Geneva, 2003.

Kawai, S., Nakagawa, M., Ohashi, H. (2002) Degradation mechanisms of a nonphenolic $\beta-\mathrm{O}-4$ lignin model dimer by Trametes versicolor laccase in the presence of 1-hydroxybenzotriazole. Enzyme Microb. Technol. 30:482-489.

Kirk, T.K., Farrell, R.L. (1987) Enzymatic "combustion": The microbial degradation of lignin. Annu. Rev. Microbiol. 41: 465-505.

Koshijima, T., Watanabe, T. Association Between Lignin and Carbohydrates in Wood and Other Plant Tissues. Springer, Berlin, 2003.

Liitiä, T.M., Maunu, S.L., Hortling, B., Toikka, M., Kilpeläinen, I. (2003) Analysis of technical lignins by two- and three-dimensional NMR spectroscopy. J. Agric. Food Chem. 51: 2136-2143.

Martínez, A.T., Speranza, M., Ruiz-Dueñas, F.J., Ferreira, P., Camarero, S., Guillén, F., Martínez, M.J., Gutiérrez, A., del Río, J.C. (2005) Biodegradation of lignocellulosics: Micro- biological, chemical and enzymatic aspects of fungal attack to lignin. Int. Microbiol. 8:195-204.

Paice, M.G., Bourbonnais, R., Reid, I.D., Archibald, F.S., Jurasek, L. (1995) Oxidative bleaching enzymes: A review. J. Pulp Pap. Sci. 21:J280-J284.

Poppius-Levlin, K., Tamminen, T., Rajanen, K., Jääskeläinen, A.-S. (1999a) Suitability of laccase/mediator systems for hardwood kraft pulp delignification. In: Proceedings of the 10th ISWP Conference, Yokohama, 7-10 June, 1999.

Poppius-Levlin, K., Wang, W., Tamminen, T., Hortling, B., Viikari, L., Niku-Paavola, M.-L. (1999b) Effects of laccase/HBT treatment on pulp and lignin structures. J. Pulp Pap. Sci. 25: 90-94.

Ralph, J., Marita, J.M., Ralph, S.A., Hatfield, R.D., Lu, F., Ede, R.M., Peng, J., Quideau, S., Helm, R.F., Grabber, J.H., Kim, H., Jimenez-Monteon, G., Zhang, Y., Jung, H.-J.G., Landucci, L.L., MacKay, J.J., Sederoff, R.R., Chapple, C., Boudet, A.M. (1999) Solution-state NMR of lignin. In: Advances in Lignocellulosics Characterization. Ed. Argyropoulos, D.S. Tappi Press, Atlanta, GA. pp. 55-108.

Ralph, J., Akiyama, T., Kim, H., Lu, F.C., Schatz, P.F., Marita, J.M., Ralph, S.A., Reddy, M.S.S., Chen, F., Dixon, R.A. (2006) Effects of coumarate 3-hydroxylase down-regulation on lignin structure. J. Biol. Chem. 281:8843-8853.

Ralph, S.A., Ralph, J., Landucci, L. (2004) NMR Database of Lignin and Cell Wall Model Compounds. US Forest Products Laboratory, Madison, WI. Available at http://ars.usda.gov/ Services/docs.htm?docid=10491, accessed July 2006.

Roost, C., Lawoko, M., Gellerstedt, G. (2003) Structural changes in residual kraft pulp lignins. Effects of kappa number and degree of oxygen delignification. Nord. Pulp Pap. Res. J. 18: 395-399.

Sarkanen, K.V., Hergert, H.L. (1971) Classification and distribution. In: Lignins-Occurrence, Formation, Structure and Reactions. Eds. Sarkanen, K.V., Ludwig, C.H. Wiley-Interscience, New York. pp. 43-94.

Sealey, J., Ragauskas, A.J. (1998) Residual lignin studies of laccase-delignified kraft pulps. Enzyme Microb. Technol. 23: $422-426$

Sealey, J.E., Runge, T.M., Ragauskas, A.J. (2000) Laccase Nhydroxybenzotriazole full sequence bleaching with hydrogen peroxide and chlorine dioxide. Tappi J. 83:1-8.

Shatalov, A.A., Evtuguin, D.V., Pascoal Neto, C. (1999) (2-O- $\alpha-$ D-galactopyranosyl-4-O-methyl- $\alpha$-D-glucurono)-D-xylan from Eucalyptus globulus Labill. Carbohyd. Res. 320:93-99.

Tamminen, T., Kleen, M., Ohra-aho, T., Poppius-Levlin, K. (2003) Chemistry of mediated-laccase delignification analyzed by pyrolysis-GC/MS. J. Pulp Pap. Sci. 29:319-324.

Xu, Q., Qin, M., Shi, S., Jin, L., Fu, Y. (2006) Structural changes in lignin during the deinking of old newsprint with laccasevioluric acid system. Enzyme Microb. Technol. 39:969-975.

Zhang, L.M., Gellerstedt, G. (2007) Quantitative 2D HSQC NMR determination of polymer structures by selecting suitable internal standard references. Magn. Reson. Chem. 45:37-45.

Received January 29, 2007. Accepted April 4, 2007.

Published online August 14, 2007. 